\title{
Chemical-free Processing of Sweet Sorghum Juice of Cultivar Sucrosorgho 506
}

\author{
Edit Cséfalvay ${ }^{1,2 *}$, Zoltán Bakacsi $^{1}$ \\ 1 Department of Chemical and Environmental Process Engineering, Faculty of Chemical Technology and Biotechnology, Budapest \\ University of Technology and Economics, H-1521 Budapest, P.O.B. 91, Hungary \\ 2 Department of Energy Engineering, Faculty of Mechanical Engineering, Budapest University of Technology and Economics, \\ H-1521 Budapest, P.O.B. 91, Hungary \\ *Corresponding author, email: csefalvay@mail.bme.hu
}

Received: 06 February 2018, Accepted: 27 April 2018, Published online: 14 June 2018

\begin{abstract}
The development of sweet sorghum syrup producing technology for the juice of cultivar Sucrosorgho 506 was completed. The applicability of different existing syrup production technologies including sugar beet-based sugar production technology, and sugar cane processing technology was also tested. The new chemical-free syrup production technology was realized at laboratory-scale and large laboratory-scale. The proposed technology offers a chemical free separation and concentration of carbohydrates, and consists of centrifugal separation; ultrafiltration extended with an approved sterilization followed by nanofiltration to separate carbohydrates and inorganics, and finally a vacuum evaporation to reach syrup state. By using this technology the initial glucose:fructose:sucrose ratio could be preserved in the syrup, therefore not limiting its further use. The possible food application was established by sensory analysis. It was revealed that the syrup produced via the developed process obtained the most attractive character that enables the opportunity to use as natural sweetener.
\end{abstract}

Keywords

centrifugal separation, chemical-free process, membrane filtration, sterilization, sweet sorghum juice, syrup production

\section{Introduction}

Sorghum vulgare var. saccharatum or Sorghum bicolor (hereinafter referred to as sweet sorghum) was proposed as a potential sugar source in 1975 [1], however two years later the idea of its utilization to produce energy came into focus of the interest [2]. Due to its high biomass productivity and high sugar content sweet sorghum was considered as an attractive multi-purpose crop.

Cultivation of sorghum vulgare var. sudanense was started in the late 1950s in Hungary [3] and it was succeeded by the cultivation of sweet sorghum Monori Édes in the '60 [4]. Following the trends, Hungary also focused on the cultivation of species that could tolerate the different soils of the Hungarian plain aiming high-yield-green biomass used for forage and silage. Cultivars of sweet sorghum, namely Monori Édes, Róna-4 and Sucrosorgho 506 were bred and cultivated solely in the Hungarian Basin [5]. After the determination of sowing and harvesting times, cultivation experiments such as selection of soil types, types and quantity of fertilizers, herbicides [6], and the selection of the appropriate agro technics, the production of juicy cultivars started at large scale. Fig. 1 shows the optimal production areas in Hungary [7]. Further cultivation experiments proved that sufficient yield could be obtained even under extremely dry years [8].

Since sugars are encapsulated in the spongy tissues of the pith, they can be easily withdrawn in a form of juice by pressing and crushing. It should be noted that this method was a time-consuming process and sweet sorghum juice can be extracted by diffusion extraction too. Although the major part of carbohydrates can be withdrawn in the juice, a lesser, but not ignorable part remains in the bagasse. Focusing exclusively on juice and its carbohydrate content, sources indicate that it is a good source of ethanol fermentation all over the world starting from USA [9-11] via Australia [12, 13], India [14], Europe [15-17] and Africa [18] and last but not least China [19]. 


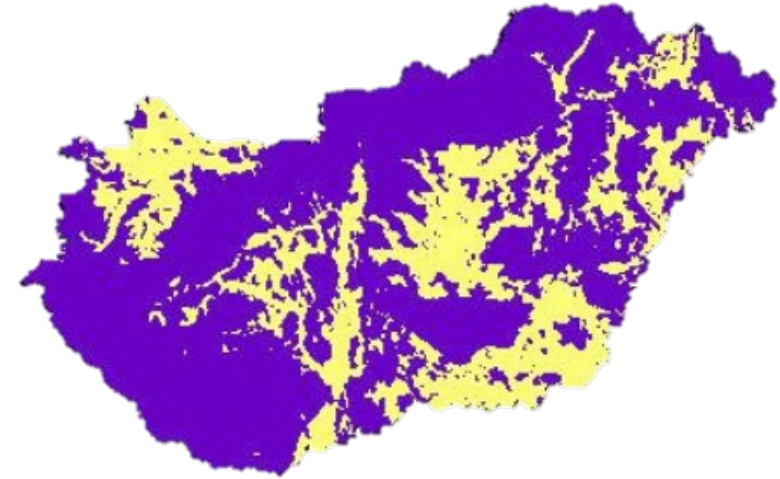

Fig. 1 The optimal cultivation areas of sweet sorghum in Hungary suggested by Fogarassy [7].

Since ethanol production techniques have been extensively studied for decades, the production of cellulosic ethanol from bagasse enhanced the total ethanol yield [2, 20-24] and gained more interest. Production of ethanol from agricultural waste (or by-products) opens up numerous source of potential feedstock. Besides ethanol other value-added chemicals can be produced from renewable feedstocks [25]. Simultaneouly efficient processes were developed for the conversion of bagasse to methane [26] or hydrogen [27-30], or $\mathrm{C}_{5}$ and $\mathrm{C}_{6}$ sugars [31, 32]. A new innovation showed that sweet sorgum fiber could be used to reinforce fly ash-based geopolymer [33] which is the latest potential use.

It is important to emphasize that utilization of sweet sorghum turned to the production of other chemical compounds from the carbohydrate content of the raw juice such as lactic acid [34-37], butanol [38], hydrogen [28, 39, 40], acetone [41], lipids [42] gained more importance. Among the platform molecules levulinic acid could play a key role in the chain [43], since it is the raw material of a proposed platform chemical (gamma-valerolactone) that can be obtained by its selective hydrogenation [44-48]. Extending the queue a new product, biopolymer generation was established by Tanamool [49] at laboratory scale.

To establish a successful biorefinery, the complete processing of every part of the plant shall be exploited offering a complex utilization $[50,51]$. The combination of biorefinery principles with a promising feedstock opens new routes for the production of a wide range of fuels and chemicals on renewables feedstock [52]. A recent review gives comprehensive conception about sweet sorghum as an energy crop and summarizes processing methods aiming a wide variety of product both from juice and bagasse [53]. Another study was specialized on biofuel production [54], and another one gives a summary of sweet sorghum as an energy crop [55]. Syrup production for nutritional purposes however, fell outside the scope of interest.

Fundamentally important parameter of processing is the storability of stalk $[56,57]$ and the preservation of juice quality as well. Due to the short-term storability more importance was given on preservation to inhibit sugar loss by uncontrolled microbial activity. Sulfur-dioxide was proposed as an efficient inhibitor [58] but nowadays sulfurdioxide is avoided since it is believed to be carcinogenic. $\mathrm{CO}_{2}$ [57], aqueous ammonia [57], propionic acid [57] and hydrogen-sulfite steam [59] were also successfully applied for stalks. Having the facility of prompt chopping and crushing of stalk, the storability task was shifted to the juice. Several solutions were proposed for juice: addition of preservatives such as ethyl-p-hydroxybenzoate [60], homogenization at $32 \mathrm{kpsi}(0.22 \mathrm{MPa})$ and ozone treatment [61], or concentration with evaporation without using additives. In the latter case; however, organic acids react with the sugars resulting a deteriorated composition [62]. The major deterioration of the extracted juice, however is caused by microbial and enzymatic activities. In spite of the changed composition, fuel production could be achieved on the basis of concentrate, but the change in organoleptic characters retains its utilization in nutrition. The preservation of the original sugar composition of the juice is still a great challenge for chemists and engineers.

The aim of sugar production from sweet sorghum juice enlightened the problems of crystallization, because the starch and aconitic acid content of juice inhibited crystallization [63]. After the removal of these critical compounds, $62 \mathrm{~kg}$ sugar and 45 litres of high-test molasses from a ton of sweet sorghum can be produced an approximate $10 \mathrm{wt} . \%$ yield in pilot-scale using cane juice processing technology [64]. Later on the easily obtainable and inexpensive white sugar turned the focus of juice utilization on biofuel purposes, whereas the difference between the chemical composition of juice and syrup has no effect on subsequent utilization. The biofuel-purpose syrup is usually processed as follows: the juice is pressed from the chopped stalks by multi-roller mills then filtered to remove the trash. The cleared juice enters the evaporator, where proteins coagulate [62] and depending on evaporation conditions several reactions could take place such as degradation of sucrose, glucose and fructose, formation of organic acids concomitant with color formation [65]. Perhaps $\mathrm{pH}$ has great influence on the decomposition reactions but simultaneously oligomerisation of monosaccharides can 
take place as well [66]. The juice is skimmed to remove the undesired compounds that rise to the top, then the canned syrup is sent for ethanol fermentation.

Since the impurity profile of sweet sorghum differs from that of sugar cane, its' processing covers more challenges. By clarification of raw juice more pure and more suitable syrup could be produced to maintain a yearround feed supply of fuel production [67]. The aims of clarification are i) remove starch, ii) capture impurities (mainly suspended solids) and iii) stabilize juice. It should be noted that starch could be indirectly removed by its hydrolysis at elevated temperature by the addition of heat-stable $\alpha$-amylase [68], but the usual way is the liming. Physical methods including sedimentation, juice clarification and filtration are better at removing sweet sorghum starch [69]. In order to avoid the degradation of glucose and fructose under alkaline conditions at 55-60 ${ }^{\circ} \mathrm{C}[70]$ Eggleston and co-workers fine-tuned clarification experiments by means of temperature and $\mathrm{pH}$ adjusted by milk of lime. They proved that heat alone does not sufficient for a complete clarification, but a minimum limed juice $\mathrm{pH}$ of 6.3-6.5 was optimal for a pre-heated juice (80-85 $\left.{ }^{\circ} \mathrm{C}\right)$. Moreover the subsequent addition of 5 ppm polyanionic flocculant resulted in clearest juice with lowest starch and impurities content. This process was worked out for cultivar Topper however, they emphasized that different cultivars have a significant effect on clarification performance [71]. Accordingly, pilot-scale studies were performed with the optimized conditions. During the evaporation of clarified juice; however, a loss of fermentable sugar was observed, which was induced by the acidic $\mathrm{pH}$ of 6.3 [72]. Latest results introduced a technology providing stabilized juice: the juice was heated to $80{ }^{\circ} \mathrm{C}$, limed to $\mathrm{pH}$ 6.5 , then 5 ppm polyanionic flocculant was added, finally it was irradiated with UV-C. It was revealed that clarification with milk of lime can protect the glucose and fructose from alkaline degradation reactions [73]. By using this technology at $25^{\circ} \mathrm{C}, 48$ hour-long storable, stabilized juice could be produced with acceptable spoilage [74]. In spite of the attracting results, the glucose : fructose : sucrose ratio has not been discussed.

We report here the comparison of three different methods for syrup production: sugar beet and sugar cane processing technology and a newly developed chemical-free process. The juice of cultivar Sucrosorgho 506, cultivated in Hungary was used for clarification and concentration experiments aiming to produce a consumable syrups that preserves the original glucose : fructose : sucrose ratio.

\section{Materials and methods}

\subsection{Key properties of cultivar Sucrosorgho 506}

The key properties of cultivar Sucrosorgho 506 grown in Hungary are summarized in Table 1.

During the harvest, the fibrous rind-leaves and panicles were separated from the stalks then chopped into approx. $10 \mathrm{~cm}$-long pieces as suggested by Broadhead [75]. The sugar-laden pith fraction was extracted by manual milling procedures. The juice was filtered through a screen to remove the large particles of trash, and mainly destructed plant materials then it was collected into $1 \mathrm{~L}$ volume sterile flasks. Samples were frozen to $-20{ }^{\circ} \mathrm{C}$ till further use to avoid both microbial activity and deterioration of carbohydrates. Samples were unfrozen right before experiments.

\subsection{Composition of juices}

The composition of raw juices differs every year according to the water- and sugar content of the plant, which depends on the annual growing conditions such as rainfall, sunshine hours in growth-time and inhomogeneity of nutrients in soil. Despite the same field, there can be difference between $1 \mathrm{~L}$ volume juice samples, because of the inhomogeneity of carbohydrate content in the plant itself and due to the accidental difference of fertilizer concentration on field during cultivation. Table 2 shows the annual compositions change of raw juices.

Table 1 Composition of Sucrosorgho 506 stalks planted in 2009 at Halmaj Hungary, maturity 167 days.

\begin{tabular}{lc}
\hline Parameter (unit) & Average values \\
\hline Dry matter (wt.\%) & $24.54 \pm 0.23$ \\
Ash content (wt.\%) & $5.43 \pm 0.02$ \\
Glucose content (mg/g dry matter) & $124.7 \pm 6.2$ \\
Fructose content (mg/g dry matter) & $97.0 \pm 4.9$ \\
Sucrose content (mg/g dry matter) & $179.7 \pm 9.0$ \\
Total carbohydrates (mg/g dry matter)* & $401.4 \pm 20.1$ \\
\hline$*$ Carbohydrate content measured on the $167^{\text {th }}$ day after sowing.
\end{tabular}

Table 2 The annually changing average composition of extracted raw juices.

\begin{tabular}{lccc}
\hline $\begin{array}{l}\text { Year/average } \\
\text { precipitation }(\mathrm{mm})[76]\end{array}$ & $\mathbf{2 0 0 9 / ( 5 9 8 . 0 )}$ & $\mathbf{2 0 1 3} /(649.6)$ & $\mathbf{2 0 1 4} /(739.8)$ \\
\hline Glucose (g/L) & $22.0 \pm 6.0$ & $21.7 \pm 1.1$ & $9.7 \pm 0.5$ \\
Fructose (g/L) & $21.9 \pm 5.2$ & $15.4 \pm 0.8$ & $10.1 \pm 0.5$ \\
Sucrose (g/L) & $159.5 \pm 32.3$ & $120.3 \pm 6.0$ & $98.6 \pm 4.9$ \\
Total carbohydrates (g/1) & $203.4 \pm 43.5$ & $157.4 \pm 7.9$ & $118.4 \pm 5.9$ \\
${ }^{\circ}$ Brix & $21 \pm 2.9$ & $13.5 \pm 0.9$ & $12.1 \pm 0.9$ \\
Dry matter content (wt.\%) & 17.64 & 15.08 & 12.70 \\
pH & $4.91-5.07$ & $5.00-5.03$ & $5.15-5.32$ \\
\hline
\end{tabular}


Year 2009 was extremely dry in Hungary causing higher dry matter content than observed in years 2013 and 2014. In comparison to other locations juice withdrawn in year 2014 possessing a Brix value of $12.1 \pm 0.9$ is in good agreement with that of measured in Italy (12.08 \pm 0.50$)$ [77] (see Table 2). Both of them were harvested similarly (after 160 days after sowing).

\subsection{Syrup production methods}

Three different syrup production methods were applied for sweet sorghum juice. Sugar beet processing technology aiming to produce crystalline sugar was adapted to sweet sorghum juice (Method 1) at first ignoring the crystallization step. Modified sugar cane processing technology (Method 2) was also tested, but in order to develop an environmentally benign process, here we propose a chemical-free purification sequence (Method 3) aiming high sugar containing syrup and keeping the original glucose : fructose : sucrose ratio.

\subsubsection{Method 1}

The adaptation of classical sugar beet processing technology [78] to sweet sorghum juice was investigated as follows (Fig. 2).

$100 \mathrm{~mL}$ of juice was heated up to a given temperature $\left(50-75^{\circ} \mathrm{C}\right)$ in a double-walled Erlenmeyer flask, then milk of lime $(20 \mathrm{~g} / \mathrm{L})$ was added in droplets and stirred properly for 30 second to reach $\mathrm{pH} \sim 11$. After stirring was finished, coagulated proteins were removed from the limed juice by microfiltration using a 0.45 -micrometer-pore size membrane. To form $\mathrm{CaCO}_{3}$ precipitates $\mathrm{CO}_{2}$ was bubbled throughout the liquor until its $\mathrm{pH}$ was adjusted to 8.5 . $\mathrm{CaCO}_{3}$ can act as an adsorbent and presumably decolorize the liquor. In order to compare the adsorbent efficiency of $\mathrm{CaCO}_{3}$ and carbon black in the meantime parallel experiments were carried out by adding $\sim 1 \mathrm{~g}$ of activated carbon black as decolorizing agent. Vacuum evaporation was carried out at the same temperature as the clarification $\left(50-75{ }^{\circ} \mathrm{C}\right)$ in two phases: as the liquor reached its solubility limit it was filtered through a 0.45 -micrometerpore size microfilter to remove the remaining $\mathrm{CaCO}_{3}$ precipitates and carbon black, then the further concentration was continued until reaching a syrup phase ( $\left.65-70{ }^{\circ} \mathrm{Brix}\right)$.

\subsubsection{Method 2}

Based on experiments by Indian companies [79] the suggested technology was modified. The schematic drawing of the adapted sugar cane processing technology to sweet sorghum juice is shown in Fig. 3.

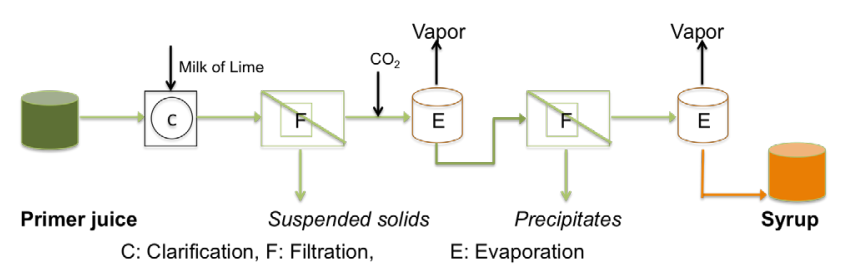

Fig. 2 Adaptation of sugar-beet processing technology to sweet sorghum juice.

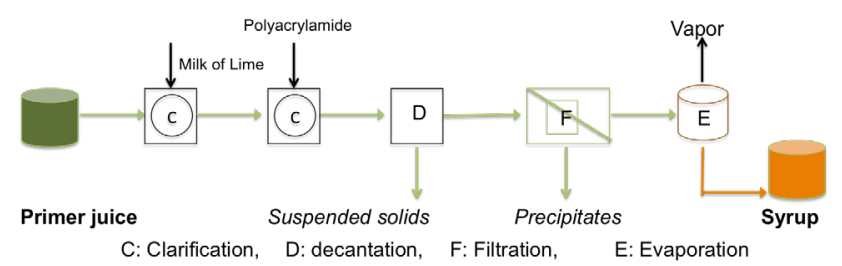

Fig. 3 Adaptation of sugar cane processing technology to sweet sorghum juice.

$100 \mathrm{~mL}$ of raw juice was heated up to a given temperature $\left(50-80{ }^{\circ} \mathrm{C}\right)$ and droplets of heated milk of lime were added to adjust the $\mathrm{pH}$ to neutral $(7.0 \pm 0.1)$. Then $0.42 \mathrm{~mL} 0.25$ wt.\% polyacrylamide stock solution was added to reach its 1-ppm-concentration in the juice. After the 30 min retention time, the decanted juice was filtered through a 0.45 -micrometer-pore size microfiltration membrane to remove all remained suspended solids. Finally the clarified juice was vacuum evaporated reaching a syrup phase $\left(65-80^{\circ} \mathrm{Brix}\right)$.

\subsubsection{Method 3}

This novel process consists of a centrifugal separation unit (CF) which eliminates the non-water soluble starch and sand, an ultrafiltration unit (UF) to remove proteins and microorganisms, a nanofiltration unit (NF) to concentrate the carbohydrate content, and a vacuum evaporation (VE) unit to further concentrate the retentate to syrup. The schematic drawing of the developed system is shown in Fig. 4. Sterilization with different sterilizing agents acceptable both for membrane and equipment was performed.

$\mathrm{CF}$ experiments were performed on a swing-out rotorequipped Rotina $380 \mathrm{R}$ (with a capacity of $4 \times 290 \mathrm{~mL}$ ) centrifuge at $5000 \mathrm{rpm}$ for $30 \mathrm{~min}$.

Ultrafiltration experiments were carried out on a CELFA P-28 universal test membrane apparatus, using a flat-sheet $\mathrm{C} 010 \mathrm{~F}$ membrane at $20^{\circ} \mathrm{C}$ and 10 bar transmembrane pressure. The effective area of the membrane was $28 \mathrm{~cm}^{2}$. The driving force was maintained by pressurizing the feed tank with inert nitrogen gas. For large-laboratory-scale experiments a $0.24 \mathrm{~m}^{2}$ membrane was used under identical conditions. 


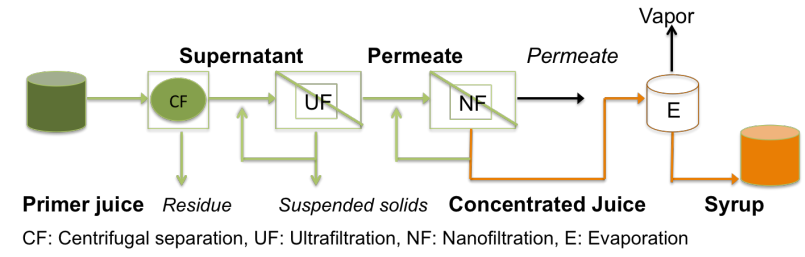

Fig. 4 Developed sweet sorghum syrup producing chemical-free processing technology.

Laboratory-scale nanofiltration experiments were carried out on a CELFA P-28 type apparatus using flat-sheet DL composite membrane at $20^{\circ} \mathrm{C}$. A pressure difference of 35 bar was maintained by nitrogen gas. For large-laboratory-scale experiments a spiral wound DL composite membrane with an effective area of $0.24 \mathrm{~m}^{2}$ was used under identical conditions. Membranes were conditioned in distilled water before the experiments. Both ultra- and nanofiltration were performed in a feed-and-bleed system i.e. the retentate was recycled to the feed tank until reaching its final volume. The recovery rates were 0.9 and 0.5 in case of ultrafiltration and nanofiltration, respectively. These values were applied at both scales.

Vacuum evaporation was carried out according to a predetermined pressure program to avoid sudden boiling, foaming and the consequent droplet distribution. The vessel was heated to $65{ }^{\circ} \mathrm{C}$ and kept constant during the experiment (Table 3).

\subsection{Analytical methods}

\subsubsection{Brix}

Brix was measured with an ATAGO PAL-1 type digital refractometer (0.0 - $53.0^{\circ}$ Brix). The Brix values of the syrups were determined on mass basis by the $1: 1$ dilution of syrup and distilled water.

\subsubsection{Dry matter content}

Dry matter (DM) was determined by heating the samples to $105^{\circ} \mathrm{C}$ for two hours. In order to avoid the formation of local hot spots and the subsequent decomposition of carbohydrates such as Maillard reaction [80], samples were mixed with doubled amount of quartz sand. Parallel experiments were conducted at $60{ }^{\circ} \mathrm{C}$ without quartz sand previously [81]. A stable $1 \mathrm{wt} . \%$-difference was observed between the DM contents measured by the two methods.

\subsubsection{Carbohydrates}

D-glucose, D-fructose and sucrose were analyzed according to D-glucose, D-fructose and sucrose Assay Procedure
Table 3 Pressure program used in vacuum evaporation.

\begin{tabular}{lcccccccc}
\hline $\begin{array}{l}\text { Pressure } \\
{[\mathbf{m m H g}]}\end{array}$ & 200 & 150 & 125 & 100 & 80 & 60 & 40 & 20 \\
\hline $\begin{array}{l}\text { Pressure } \\
{[\mathrm{kPa}]}\end{array}$ & 26.66 & 20.00 & 16.67 & 13.33 & 10.67 & 8.00 & 5.33 & 2.67 \\
\hline $\begin{array}{l}\text { Time } \\
{[\mathrm{min}]}\end{array}$ & 2 & 2 & 2 & 2 & 2 & 2 & 3 & $*$ \\
\hline
\end{tabular}

*Until reaching syrup phase.

(KSURFG 12/05) provided by Megazyme Ltd. The principles of this enzymatic determination are as follows:

The D-glucose concentration was determined before and after hydrolysis of sucrose by $\beta$-fructosidase (invertase). The D-fructose content of the sample was determined subsequent to the determination of D-glucose, after isomerization by phosphoglucose isomerase (PGI). Actually the absorption of NADPH was detected at a wavelength of $340 \mathrm{~nm}$, so its concentration was equivalent to the concentration of glucose. Because of the low detection limit and the calibration's linearity, sweet sorghum samples had to be diluted to 1000 -fold, syrups to 2000 -fold for the measurement. The accuracy of the method was $\pm 0.12 \mathrm{mg} / \mathrm{L}$ for each carbohydrate.

\section{$2.4 .4 \mathrm{pH}$}

$\mathrm{pH}$ values were continuously measured by a WTW $340 \mathrm{i}$ $\mathrm{pH} /$ conductivity meter during the addition of milk of lime and polyacrylamide, and regularly measured (before and after) each processing step.

\subsubsection{Microbial analysis}

Microbial cultures were cultivated on two types of culture-medium: agar-agar and Nutrient. Supernatant and ultrafiltration permeates were diluted and inoculated onto the substrates and after a given incubation time the cultivated microbe settlements were counted [82].

\subsubsection{Silver content}

To detect its enrichment silver concentration was determined in the syrups produced with Method 3 by atomic absorption spectroscopy at a wavelength of $328.2 \mathrm{~nm}$.

\subsubsection{Sensory analysis and descriptive analysis of syrups} The integration of sensory organs (vision, olfaction and gustation) can help to characterize food products and deliver them into general use. Assessment of sensory properties of syrups was conducted by the methodology of consumer's test. Testers determined odor in a positive sense, intensity of odor, intensity of color, flavor and aftertaste. The criteria 
for the assessors were no food, coffee and cigarette consumption within 2 hours before the analysis. A score list with 5 points was applied. In case of odor, flavor and aftertaste category scale were applied where 1 represented the worst and 5 represented the best score. Considering the intensity of odor and intensity of color a "just right" scale was used where score 0 indicated the optimum, lesser -2 and worse +2 . The group of assessors had 5 members: two females and three males. Average scores of all categories were calculated during the evaluation. The description of syrup characterization method is summarized in Table 4.

\subsubsection{Chemicals}

Calcium hydroxide ( $\geq 95.0 \%$ ) was purchased from SigmaAldrich and it was dissolved in water to get milk of lime solution (20 g/L). Polyacrylamide granules (as Magnafloc $\AA$ LT-340 product) were provided by BASF. A $0.25 \mathrm{wt} . \%$ stock solution was prepared by the dissolution of $0.1252 \mathrm{~g}$ polymer in $50 \mathrm{~mL}$ water. $96 \mathrm{wt} . \%$ ethanol and citric acid monohydrate were purchased from Molar Chemicals Ltd. and Sanosil Super 25 Ag sterilizing agent from Sanosil Hungaria Ltd., while activated carbon black was obtained from Merck.

\section{Results and Discussion}

\subsection{Evaluation of clarification by Methods 1 and 2}

Initially $100 \mathrm{~mL}$ of raw juice was heated to a given temperature. After setting the $\mathrm{pH}$ to 11 (Method 1) with milk of lime, stirring was stopped and the suspended solids were settled and loose flocks could be observed (see Fig. 5). In contrast to Method 1 at neutral $\mathrm{pH}$ the consequent addition of polyacrylamide (Method 2) resulted in bigger flocks (see Fig. 6). Considering the effect of temperature, the color of the clarified liquor changed from orange to reddish-brownish indicating the decomposition reactions of glucose and fructose at alkaline $\mathrm{pH}$ (Method 1) [65] while the change in color was not significant in Method 2: the color of clarified

Table 4 The description of the sensory analysis (ideal score is 15).

\begin{tabular}{lcccc}
\hline Parameter & Ranking & Best score & Scale type & Notes \\
\hline Odor (positive sense) & $1-5$ & 5 & Structured & 1: worst, 5: best \\
Intensity of odor & $-2-+2$ & 0 & "just right” & -2 : no smell, 2: too intensive \\
Intensity of color & $-2-+2$ & $0 *$ & "just right” & $\begin{array}{l}-2: \text { lighter than honey } \\
+2: \text { darker than honey }\end{array}$ \\
Flavor & $1-5$ & 5 & Structured & $\begin{array}{l}\text { 1: worst, 5: best } \\
\text { Overall impression }\end{array}$ \\
Aftertaste & $1-5$ & 5 & Structured & 1: worst, 5: best
\end{tabular}

* similar to honey

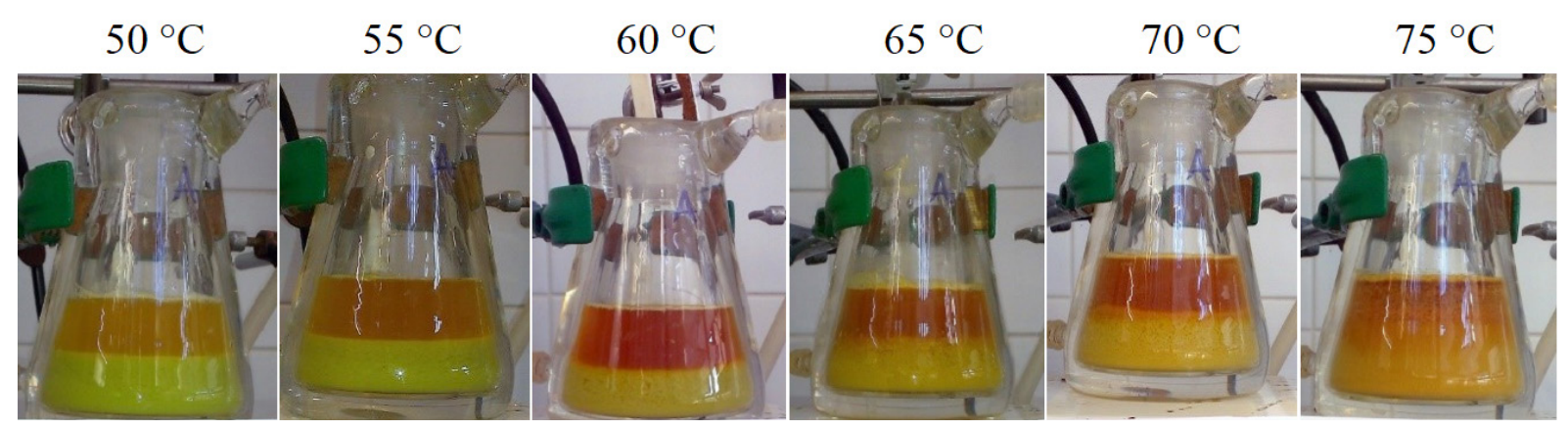

Fig. 5 Effect of temperature in clarification by milk of lime during Method 1.

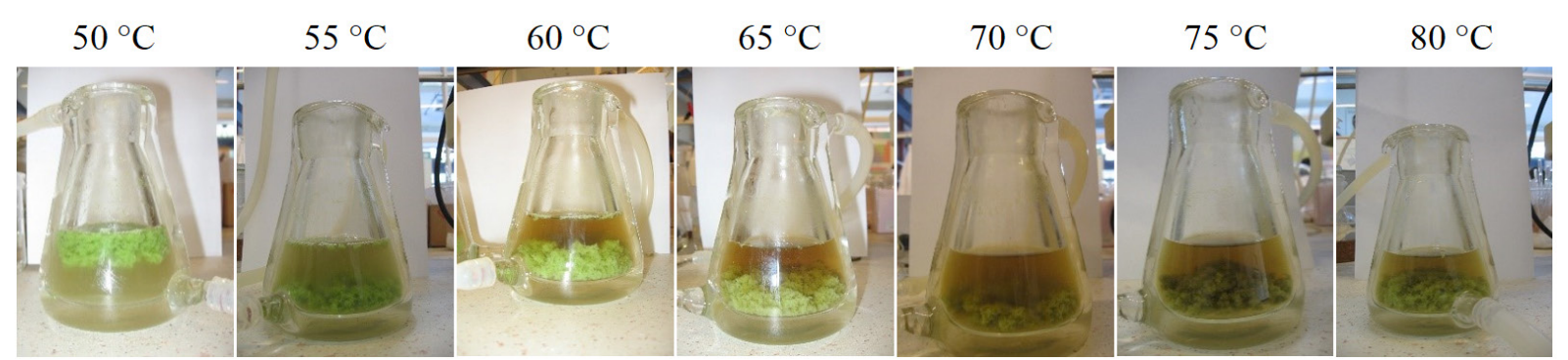

Fig. 6 Effect of temperature in clarification by milk of lime and polyacrylamide during Method 2. 
liquor turned from light green to light brown with increasing temperature. Our assumption based on color change was verified by the analysis of glucose, fructose and sucrose concentrations of clarified juices and syrups (see later in paragraph Carbohydrate content of syrups). Although the clarified juices produced in Method 2 seemed to be pure, carbohydrate monomers were decomposed under these conditions as well as in Method 1. The carbohydrate concentrations of syrups formed by the forthcoming vacuum evaporation were far away from the expected $\sim 60-70{ }^{\circ} \mathrm{Bx}$ syrup concentrations.

\subsection{Evaluation of Method 3: Development of chemical- free processing technology}

\subsubsection{Centrifugal separation (CF)}

Engineering calculations showed that gravitational sedimentation would last for days, which would enhance the deterioration of carbohydrates. Centrifugal separation is a good choice to accelerate the settling of particles (sand, starch and colloidal state cell fragments). 20 min centrifugal separation time at $5000 \mathrm{rpm}$ was proven to be sufficient for the pretreatment of sweet sorghum juice and provided appropriately purified feedstock for biomass conversion [43]. If the centrifugal separation time is elongated to $30 \mathrm{~min}$ the particles under 0.3-micrometer-diameter can settle, as well. It should be noted that the raw juice composition varies from year to year so an average retention time of $30 \mathrm{~min}$ at an rpm between 2500-5000 would be required for efficient separation.

In general, by increasing the centrifugal separation time the ratio of the residue and the liquor increases although, no direct relation could be observed by time and rpm. The varying total dissolved solid (TDS) and dry matter (DM) content had more significant effect on the separation. The high standard deviation represents the inhomogeneity of juices [83].

\subsubsection{Ultrafiltration (UF)}

The average permeate flux (calculated from 17 parallel experiments) of the properly selected membrane is shown in Fig. 7. Standard deviation is extremely high at the beginning of the filtration and later it refers to $25 \%$ provided by the membrane supplier. Recovery rate is indicated by $\mathrm{V}_{\mathrm{p}} / \mathrm{V}_{\mathrm{f}}$ as the volume of permeate related to the volume of the feed. Although the carbohydrate content of feed varies according to the annual variation of juice composition, the flux could be stabilized between $35-45 \mathrm{~L} /\left(\mathrm{m}^{2} \mathrm{~h}\right)$ at $20{ }^{\circ} \mathrm{C}$ and 10 bar transmembrane pressure. Sasaki and coworkers [84] performed purification of raw juice of cultivar SIL05 by
Table 5 Characterization of centrifugal separation experiments.

\begin{tabular}{lccccc}
\hline $\begin{array}{l}\text { Centrifuging } \\
\text { time (min) }\end{array}$ & Rpm & $\begin{array}{c}\text { Rotational } \\
\text { centrifugal } \\
\text { force (RCF) }\end{array}$ & $\begin{array}{c}\text { No. of } \\
\text { exp. }\end{array}$ & $\begin{array}{c}\text { Average } \\
\text { of residue } \\
\text { (TDS) } \\
\text { (wt.\%) }\end{array}$ & $\begin{array}{c}\text { Standard } \\
\text { deviation } \\
\text { (wt.\%) }\end{array}$ \\
\hline 30 & 5000 & 5870 & 63 & 3.95 & 3.38 \\
\hline
\end{tabular}

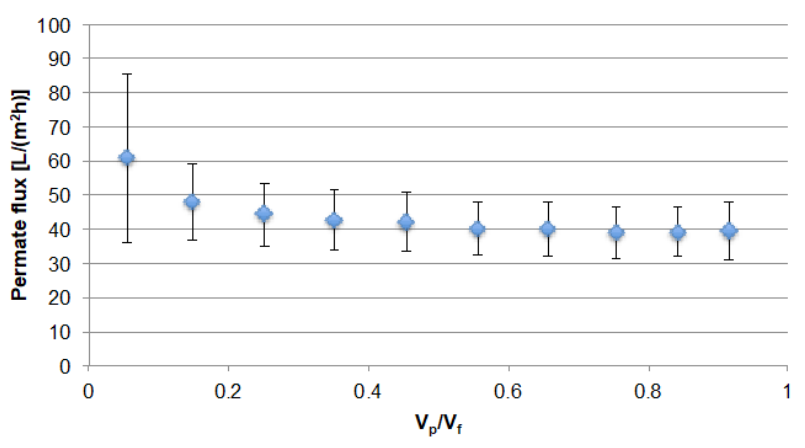

Fig. 7 Average flux and calculated standard deviation for UF membrane, $20^{\circ} \mathrm{C}$ and $10 \mathrm{bar}$.

ultrafiltration at 4 bar however, flux values and composition of permeates were not published, since they focused on the forthcoming ethanol production by fermentation.

The sterilization of membrane apparatus seemed to be a key issue during ultrafiltration, because of the traces of carbohydrates remaining in the feed tank after washing alimenting the filtered microorganism with carbon source. Three sterilizing agents were tested at recommended concentrations (70 wt.\% ethanol, citric acid solution at $\mathrm{pH}=2$, and Sanosil Super $25 \mathrm{Ag}$ ).

According to the microbial cultivation, feed solutions (CF supernatants) contained $968 \mathrm{CFU} / \mathrm{mL}$ fungi and $6633 \mathrm{CFU} / \mathrm{mL}$ bacteria. Unfortunately, the cultivars on agar-agar were infected giving a positive false result, therefore UF permeate samples must have been tested on Nutrient substrate as well (see results in Table 6).

While all permeates stored at $4{ }^{\circ} \mathrm{C}$ seemed uninfected, uncountable numbers of microorganism grew on permeates stored at ambient temperature in samples produced after sterilization with ethanol or citric acid. The $\mathrm{H}_{2} \mathrm{O}_{2}$ and silver containing Sanosil Super $25 \mathrm{Ag}$ provided the only germ-free sample. It has to be emphasized that nobody has drawn attention on the importance of sterilization of membranes and equipment yet.

\subsubsection{Nanofiltration (NF)}

After the selection of the appropriate nanofiltration membrane [85] UF permeates were further concentrated with DL type NF membrane allowing the water and dissolved 
Table 6 Results of microbial cultivations of permeates produced in UF after using different sterilizing agents on Nutrient substrate.

\begin{tabular}{lcc}
\hline Sterilizer & $\begin{array}{c}\text { Microorganisms } \\
(\mathbf{C F U} / \mathbf{m L}) \text { in } \\
\text { samples stored } \\
\text { at } \mathbf{4}^{\circ} \mathbf{C}\end{array}$ & $\begin{array}{c}\text { Microorganisms } \\
(\mathbf{C F U} / \mathbf{m L}) \text { in samples } \\
\text { stored at ambient } \\
\text { temperature }\end{array}$ \\
\hline 70 wt.\% ethanol & 77 & uncountable \\
Citric acid $\mathrm{pH}=2$ & 520 & uncountable \\
Sanosil super $25 \mathrm{Ag}$ & 0 & 0 \\
\hline
\end{tabular}

salts to pass through while concentrating the carbohydrates in the retentate. Pressure difference $(\Delta p)$ of 35 bar was maintained by nitrogen to supply the driving force (trans-membrane pressure $=\Delta \mathrm{p}-\Delta \pi$ ) for the separation process and compensate the increasing osmotic pressure $(\Delta \pi)$. Continuous concentration and the consequently increasing osmotic pressure resulted in a continuously decreasing flux. Because of the application of UF provided a relatively homogenous permeate used as NF feed, stable nanofiltration flux could be observed providing much lower standard deviations than that of UF fluxes. The average NF fluxes (calculated from 9 parallel experiments) were labeled with dots and marked standard deviation (see Fig. 8). The fluxes of juices harvested in different years are in the range of standard deviations, which verifies the rigidity of the selected pretreatment technology. The flux obtained during large-lab scale nanofiltration was in agreement with the lab-scale flux, as expected. However emphasis should be given, on the proper washing and cleaning of membranes. Of the different combinations of sterilizers (Table 7) Sanosil Super 25 Ag was successfully used to sterilize the UF and NF membranes, too. Because the membrane equipment was in a semi-batch (or feedand-bleed) mode i.e. raw juice is fed at ones and permeate was removed continuously until the feed volume reached the lower limit of operation when the experiment had to be stopped. Then feed tank was sterilized because the circulation flow allowed the contact with the membrane

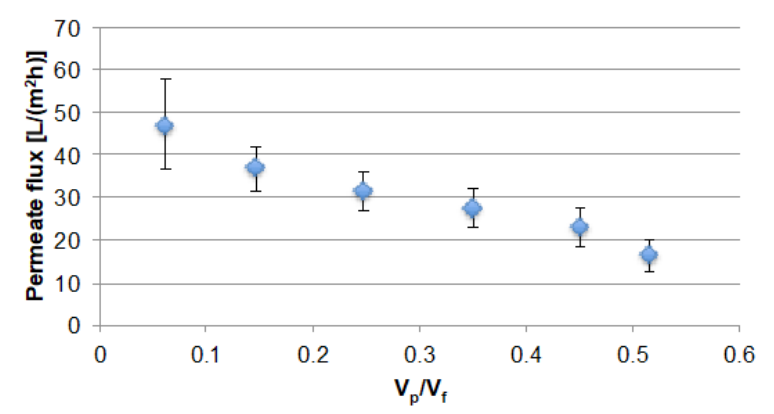

Fig. 8 Nanofiltration fluxes at $20^{\circ} \mathrm{C}$ and 35 bar.
Table 7 Combination of different sterilizing agents E=ethanol, $\mathrm{CA}=$ citric acid, $\mathrm{S}=$ Sanosil Super $25 \mathrm{Ag}$.

\begin{tabular}{|c|c|c|c|c|c|c|c|}
\hline Sample No. & 1 & 2 & 3 & 4 & 5 & 6 & 7 \\
\hline $\begin{array}{l}\text { Sterilizing } \\
\text { agent used } \\
\text { for UF }\end{array}$ & $\begin{array}{c}70 \\
\text { wt. } \% \\
\text { E }\end{array}$ & $\begin{array}{c}70 \\
\text { wt. } \% \\
\text { E }\end{array}$ & $\begin{array}{c}\mathrm{pH}=2 \\
\mathrm{CA}\end{array}$ & $\begin{array}{c}\mathrm{pH}=2 \\
\mathrm{CA}\end{array}$ & $\begin{array}{c}\mathrm{pH}=2 \\
\mathrm{CA}\end{array}$ & $\begin{array}{c}50 \% \\
\mathrm{~S}\end{array}$ & $\begin{array}{c}50 \% \\
\mathrm{~S}\end{array}$ \\
\hline $\begin{array}{l}\text { Sterilizing } \\
\text { agent used } \\
\text { for NF }\end{array}$ & $\begin{array}{c}0.5 \% \\
\mathrm{~S}\end{array}$ & $\begin{array}{c}0.5 \% \\
\mathrm{~S}\end{array}$ & $1 \% \mathrm{~S}$ & $1 \% \mathrm{~S}$ & $1 \% \mathrm{~S}$ & $\begin{array}{c}10 \% \\
\mathrm{~S}\end{array}$ & $\begin{array}{c}10 \% \\
\mathrm{~S}\end{array}$ \\
\hline
\end{tabular}

therefore, feed tank and membrane could be sterilized at the same time. No chemicals were added to the permeates.

Long-term storability experiments of NF retentates (lasted for 3 months) showed that samples stored in a sterile, tightly closed flask at room temperature could keep their carbohydrate content and no microbial infection was observed. Moreover, samples No. 6 and 7 (sterilized only with Sanosil super $25 \mathrm{Ag}$ ) could be stored even for 3 years without any loss of sugar. Compared to the clarification results of Eggleston and coworkers [86] attained with cultivar Topper, we increased the storability time with several orders of magnitude ( 3 years vs. 48 hours) by this novel technology in case of cultivar Sucrosorgho 506.

\subsubsection{Vacuum evaporation (VE)}

By the end of NF according to general 14.06\% carbohydrate loss during $\mathrm{CF}+\mathrm{UF}+\mathrm{NF}$ (CF residue contains $2.38 \%$, UF retentate $10.2 \%$, NF permeate $1.48 \%$ of the initial carbohydrate content), an average $25{ }^{\circ}$ Brix retentate could be produced. To reach a syrup phase, further concentration was performed by vacuum evaporation. Moderate heating at $65{ }^{\circ} \mathrm{C}$ and final $20 \mathrm{mmHg}(2.66 \mathrm{kPa})$ vacuum was sufficient for the concentration. The average ${ }^{\circ}$ Brix of syrups was 66 , which indicates that with evaporation the carbohydrate content could be doubled (Fig. 9).

\subsubsection{Carbohydrate content of syrups}

The analysis of glucose, fructose and sucrose concentrations of syrups proved our assumptions: 66-100 wt.\% of glucose and 72-100 wt.\% of fructose decomposed during the application of Method 1. The initial glucose : fructose : sucrose mass ratio (initially $1.3: 1: 8.5$ ) completely changed to an average ratio of $1.6: 1: 38.7$, clearly indicating that by this method the sucrose could be preserved exclusively, and our aim to maintain the initial ratio of carbohydrates was failed (therefore no figure on carbohydrate content is provided). With increasing temperature monomers degraded under alkaline $\mathrm{pH}$, similarly as observed by Eggleston [70]. Color change could be caused 


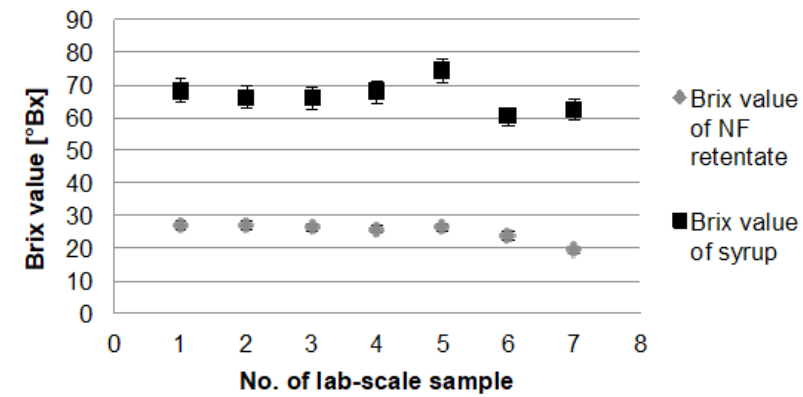

Fig. 9 Brix values of nanofiltration retentates and syrups produced by vacuum evaporation.

by formation of organic acids [65]. No difference could be observed between samples with and without carbon black.

In case of Method 2 however, all three types of carbohydrates could be preserved in the juice and consequently in the syrup. To depict all carbohydrates on the same graph, the logarithmic scaled concentrations of carbohydrate content of syrups are shown in Fig. 10. While brownish sucrose syrup could be produced with Method 1, an approximately constant ratio of glucose, fructose and sucrose could be maintained with Method 2, which resulted in honey-like colored syrup, almost independently of temperature. The deviations can be explained by the slightly different Brix values of syrups. Considering the loss of sugar during Method 2, 21-44\% of the initial total sugar went absent, probably bound on the surface of polyacrylamide flocks.

In case of the chemical-free technology represented by Method 3, higher concentrations of glucose and fructose could be observed in the syrup than in previous cases (Fig. 11). The variation trend between samples 1-7 for glucose is the same as for fructose and sucrose and can be obviously explained by the different enrichment factors obtained during vacuum evaporation. The loss of sugar manifests only in the UF retentate and the NF permeate.

UF retentate represents almost $10 \%$ of the initial mass and carbohydrate as well, and having a similar distribution of sugars, which proves that UF is not selective for carbohydrates but selective for proteins.

NF permeate represents $40 \%$ of the initial mass, having a total carbohydrate concentration of $5.63 \mathrm{~g} / \mathrm{L}$, and almost $2 / 3^{\text {rd }}$ of it is glucose, $1 / 3^{\text {rd }}$ fructose and only $7 \%$ is sucrose (Fig. 12). This loss of monosaccharides results in a lower concentration of glucose and fructose in the NF retentate, but compared to the decrease obtained in Methods 1 and 2 the decrease be can be neglected. However, heating the NF retentate to $65^{\circ} \mathrm{C}$ for the vacuum evaporation resulted

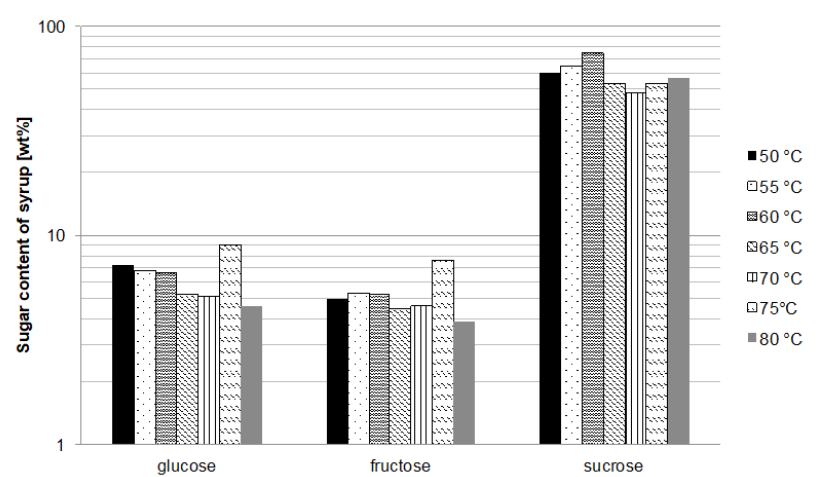

Fig. 10 Logarithmic scale representation of glucose, fructose and sucrose concentrations in the syrups produced with Method 2.

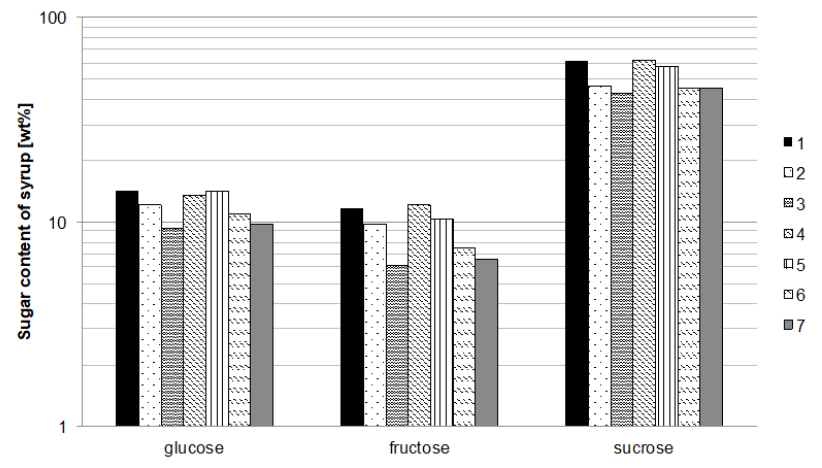

Fig. 11 Logarithmic scale representation of glucose, fructose and sucrose concentrations in the syrups produced with Method 3.

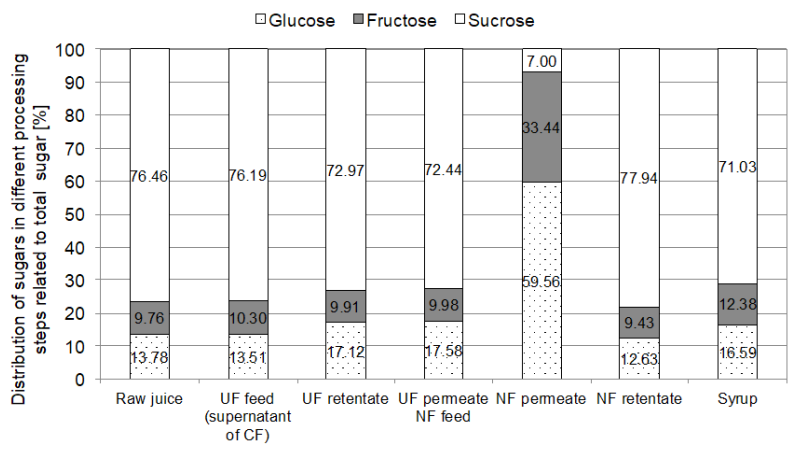

Fig. 12 Distribution of carbohydrates in each effluent of Method 3.

a decay of $7 \%$ sucrose to a 1:1 ratio glucose and fructose thus increasing the monosaccharides' concentration in the syrup by $3.5 \%$ each.

\subsection{Sensory analysis}

The scores given in each category of sensory analysis are depicted on radar charts. The curves located the most of all outside show the finest syrup from each charge. Syrup produced at $50{ }^{\circ} \mathrm{C}$ in Method 1 (Fig. 13) is the winner but its bittersweet aftertaste makes it acceptable only for a narrow consumer group. $60{ }^{\circ} \mathrm{C}$ is the sweetest out of syrups 


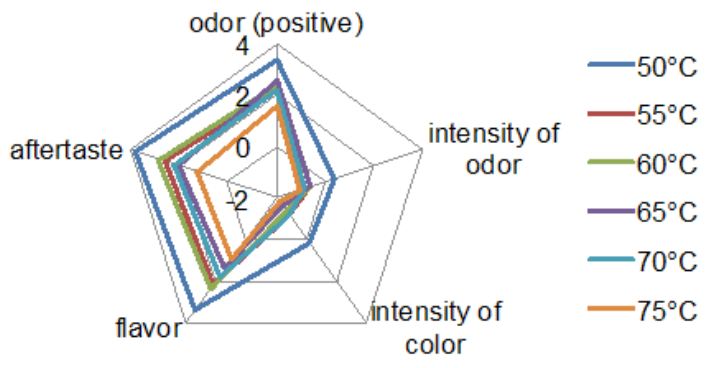

Fig. 13 Sensory analysis of syrups produced with Method 1.

produced with Method 2 (Fig. 14), and the overall opinion on these syrups is positive, they have a nice and not intensive smell and their color is lighter than honey. The only negative character was the slight bitter aftertaste, which is assumed to be the effect of liming.

In general the overall impression on syrups produced with Method 3 was positive and the bitter aftertaste was replaced by acidic aftertaste, which can be explained by the acidic $\mathrm{pH}$ of the syrups (Fig. 15). Considering the total scores summarized in Table 8, syrups produced with Method 3 attained higher scores almost in all cases. The highest scores were 11.2, 13.1 and 14.0 for syrups produced by Method 1, 2 and 3. Table 9 shows the average values of selected properties of clarified juice in cases of Methods 1 and 2, the retentate produced by nanofiltration with Method 3 and the syrups produced by the different methods.

Due to the variation in raw juices and circumstances during the final evaporation step, different concentrations could be produced. Therefore, purity of syrups seems to be a better parameter for the comparison. The average purity of syrups increases with technology improvement, and the

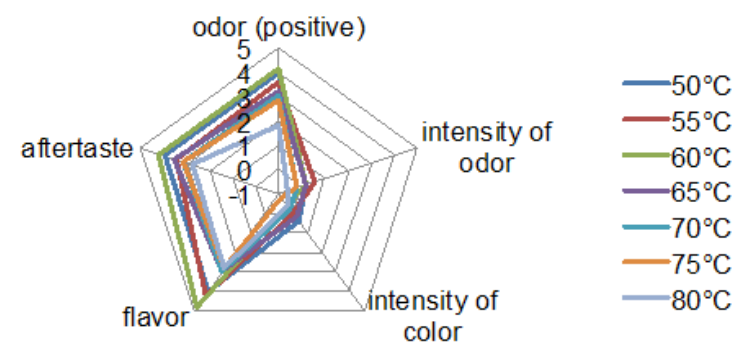

Fig. 14 Sensory analysis of syrups produced with Method 2.

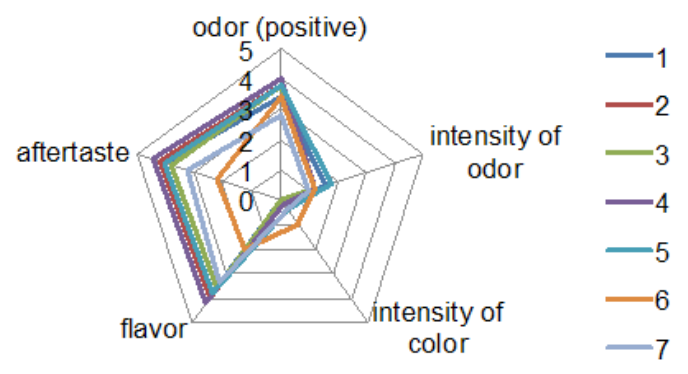

Fig. 15 Sensory analysis of syrups produced with Method 3.

Table 8 Total scores of syrups in sensory analysis, highest score highlighted with bold and italics.

\begin{tabular}{|c|c|c|c|c|c|c|c|}
\hline Circumstances & $50{ }^{\circ} \mathrm{C}$ & $55^{\circ} \mathrm{C}$ & $60^{\circ} \mathrm{C}$ & $65^{\circ} \mathrm{C}$ & $70^{\circ} \mathrm{C}$ & $75^{\circ} \mathrm{C}$ & $80^{\circ} \mathrm{C}$ \\
\hline Method 1 & 11.2 & 5.2 & 5.6 & 3.8 & 4.2 & 1.0 & - \\
\hline Method 2 & 12.6 & 11.9 & 13.1 & 10.2 & 8.8 & 7.8 & 6.4 \\
\hline Sample No. & 1 & 2 & 3 & 4 & 5 & 6 & 7 \\
\hline Method 3 & 12.8 & 13.2 & 12.4 & 14.0 & 13.8 & 9.8 & 10.8 \\
\hline
\end{tabular}

highest purity could be observed in Method 3 where no additional chemicals were used during the concentration process, and the syrups preserved almost the same $\mathrm{pH}$ as the initial

Table 9 Average properties of raw juices, clarified juices/NF retentates and syrups, n.a.: not applicable.

\begin{tabular}{|c|c|c|c|c|}
\hline & Parameter & Method 1* & Method $2 *$ & Method $3^{* *}$ \\
\hline \multirow{3}{*}{ Raw juice } & $\begin{array}{l}\text { Mass ratio } \\
\mathrm{G}: \mathrm{F}: \mathrm{S}\end{array}$ & $1.3: 1: 8.5$ & $1.3: 1: 8.6$ & $1.3: 1: 6.4$ \\
\hline & $\mathrm{pH}$ & 5.26 & 5.37 & 4.99 \\
\hline & ${ }^{\circ}$ Brix & 12.1 & 13.6 & 14.8 \\
\hline \multirow{2}{*}{$\begin{array}{l}\text { Clarified juice*/ } \\
\text { NF retentate** }\end{array}$} & $\mathrm{pH}$ & 8.50 & 7.02 & 5.09 \\
\hline & ${ }^{\circ}$ Brix & 12.2 & 14.4 & 25.0 \\
\hline \multirow{7}{*}{ Syrup } & $\mathrm{pH}$ & 8.50 & 6.93 & 5.19 \\
\hline & ${ }^{\circ}$ Brix & 66.9 & 80.4 & 66.3 \\
\hline & DM & 76.4 & 77.6 & 72.3 \\
\hline & $\begin{array}{l}\text { Mass ratio } \\
\mathrm{G}: \mathrm{F}: \mathrm{S}\end{array}$ & $1.6: 1: 38.7$ & $1.3: 1: 11.8$ & $1.4: 1: 5.8$ \\
\hline & $\begin{array}{l}\text { Total Carbohydrates } \\
\text { (TC) (wt.\%) }\end{array}$ & 38.74 & 49.54 & 51.37 \\
\hline & Purity $(\mathrm{TC} / \mathrm{DM} \times 100)$ & 50.71 & 63.84 & 71.05 \\
\hline & Silver conc. (mg/L) & n.a. & n.a. & 2.73 \\
\hline
\end{tabular}


raw juice. As long as the $\mathrm{pH}$ of juice was increased the degradation of monosaccharides resulted in a decreased purity.

\subsection{Silver content}

Due to the silver content of sterilizing agent Sanosil Super $25 \mathrm{Ag}$, silver accumulation might be expected in the syrup produced with Method 3, so it was analyzed by atomic absorption spectroscopy. Silver concentration was found to be maximum $6.96 \mathrm{ppm}$. According to US EPA a maximum oral intake of $0.005 \mathrm{mg} \mathrm{Ag} /$ body $\mathrm{kg}$ is allowed. Over this value the probability of argyrosis significantly increases. At worst case, consuming the highest Ag containing syrup, a daily $100 \mathrm{~mL}$ volume may be consumed during the lifetime of a 70-kg-weight person.

\subsection{Mass balance of Method 3}

The sankey diagram of mass balance obtained in Method 3 clearly indicates the distribution of quantities of product, by-products, reusable water and losses (Fig. 16). The syrup with an average ${ }^{\circ}$ Brix of 66.3 represents ca. $16 \mathrm{wt} . \%$ of the initial juice, and the by-products: the residue of centrifugal separation (3.95 wt.\%) and retentate of ultrafiltration (9.73 wt.\%) amount almost 14 wt.\%. These by-products can be utilized as a nutrient-supplement in animal feeding. NF permeate is indebted to by-products, but it has much less valuable compounds than $\mathrm{CF}$ residue or UF retentate, however it contains traces of carbohydrates $(5.63 \mathrm{~g} / \mathrm{L})$ therefore allowing it to be used as substrates for yeast cultivation after addition of $\mathrm{N}$ - and P-sources. The condensed vapor from evaporation step represents pure and reusable water that could be recycled to the membrane filtration steps and used as washing water. The overall loss during the proposed technology is less than $1 \mathrm{wt} . \%$. With this technology an overall yield of $16 \%$ could be attained which is 1.5 -fold higher than that of obtained previously by Angelle and coworkers [64].

\section{Conclusion}

We demonstrated that the juice of Sucrosorgho 506 cultivated in Hungary could be concentrated by modified sugar beet (Method 1) and sugar cane (Method 2) processing technologies however, the decomposition of monosaccharides was observed during the processes.

A four-step, chemical-free separation technology consisting of a CF, an UF, a NF, and a VE unit that can be used in a wide range (raw juices with total carbohydrate content varying from $118.4 \pm 5.9$ to $203.4 \pm 43.5 \mathrm{~g} / \mathrm{L}$ ) was developed. It was shown that the non-water soluble starch and sand content of the juice could easily be separated by the application $\mathrm{CF}$, while proteins and microorganisms could be removed by UF. The purified juice was concentrated with nanofiltration to an average Brix value of 25 at $20{ }^{\circ} \mathrm{C}$ and $3.5 \mathrm{MPa}$ both at laboratory, and large-laboratory scale, and further concentrated by VE. The mild conditions during $\mathrm{CF}, \mathrm{UF}$ and $\mathrm{NF}$ and the moderate temperature during VE enhanced the preservation of carbohydrates close to their original ratio. We revealed that the proper sterilization of the equipment and the membranes

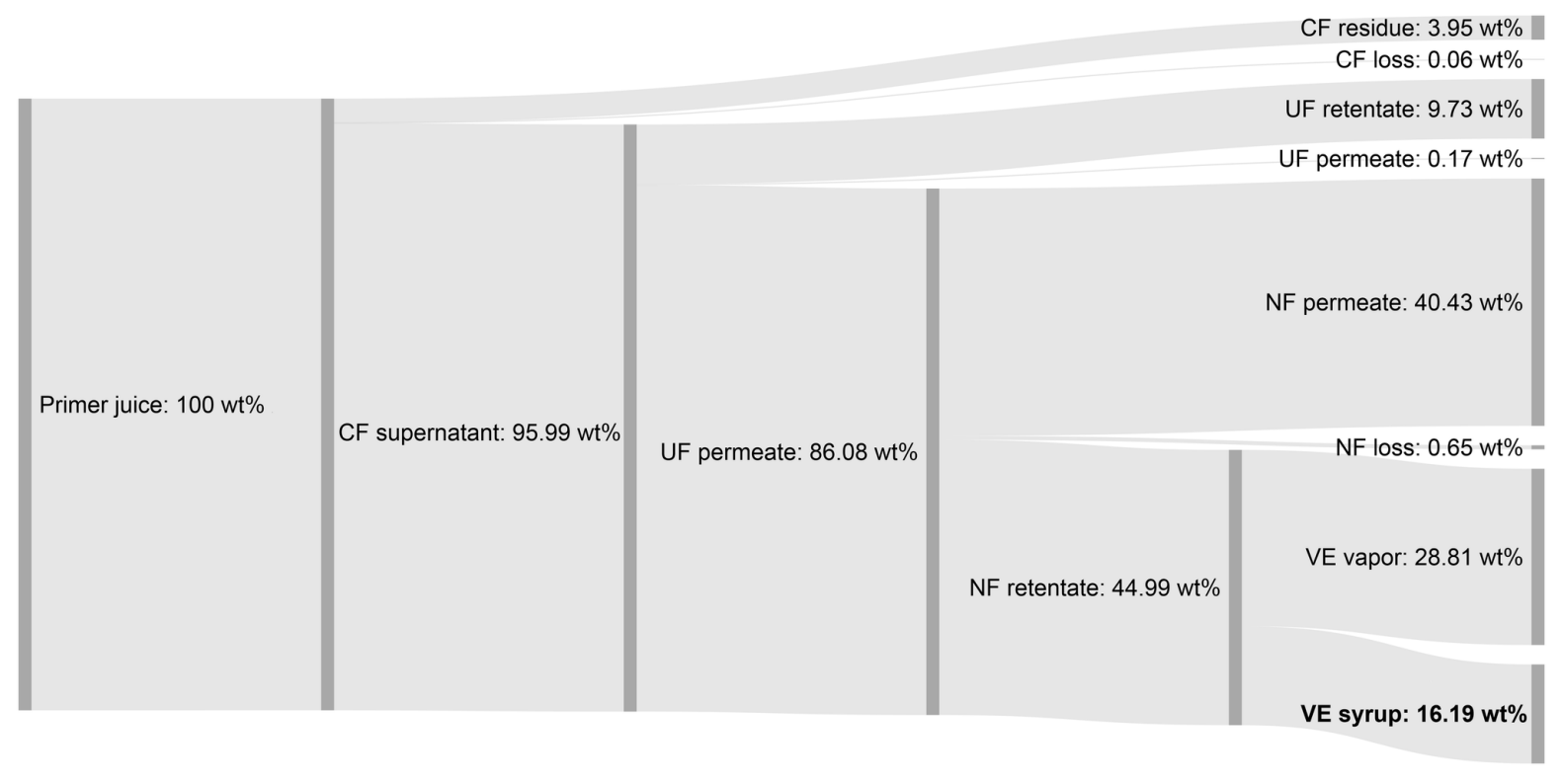

Fig. 16 Sankey diagram of developed chemical-free processing technology (Method 3), CF: centrifugal separation, UF: ultrafiltration, NF: nanofiltration, VE: vacuum evaporation. 
plays a key role in long-term storability of clear juice (NF retentate) and syrup as well. It can be stated that the use of Sanosil Super $25 \mathrm{Ag}$ is necessary at a concentration that is suitable for the applied membranes.

The highest syrup purity (71\%) was obtained in the case of our suggested technology. By maintaining the original $\mathrm{pH}$ of the juice during the process, the initial carbohydrate ratio was found to be preserved (mass ratio of glucose : fructose : sucrose were $1.3: 1: 6.4$ and $1.4: 1: 5.8$ in the raw juice and the syrup, respectively).

Sensory analysis and the individual evaluations of flavor and aftertaste reported that syrup produced with our proposed method (Method 3) was the sweetest, without any bitter flavor. However, a slight acidic aftertaste appeared due to the original acidic $\mathrm{pH}$. Considering the overall properties of syrups and impressions of the sensory analysis, we propose this four-step, chemical-free separation technology for syrup as a possible natural sweetener production from Sucrosorgho 506 raw juice. We demonstrated that food quality syrup could be produced by the proposed chemical-free technology, without compromising the syrup's further use such as conversion to platform chemicals in a future biorefinery.

\section{References}

[1] Lime, B. J., Smith, B. A. "Sweet sorghum as a Potential New Sugar Source", Abstracts of Papers of the American Chemical Society 170, 23. 1975.

[2] Sipos, B., Réczey, J., Somorai, Z., Kádár, Z., Dienes, D., Réczey, K. "Sweet Sorghum as Feedstock for Ethanol Production: Enzymatic Hydrolysis of Steam-Pretreated Bagasse", Applied Biochemistry and Biotechnology, 153, pp. 151-162, 2008. https://doi.org/10.1007/s12010-008-8423-9

[3] Kapás, S. "Magyar növénynemesítés" (Hungarian Plant Breeding), Akadémiai Kiadó, Budapest, 1969. (in Hungarian)

[4] Gyalai-Korpos, M., Feczák, J., Réczey, I. "A Monori Édes cukorcirok mint lehetséges bioetanol alapanyag", (Sweet sorghum of cultivar Monori Édes as a potentional bioethanol raw material) Bioenergia, 3, pp. 25-29, 2008. (in Hungarian)

[5] Feczák, J. "Szabad-e foglalkozni ciroktermesztéssel Magyarországon?" (Is it possible to deal with sorghum production in Hungary?), Agrofórum a növényvédők és növénytermesztők havilapja, 21, pp. 24-25, 2010. (in Hungarian).

[6] Ambrus, A., Pethes, J. "Édes Energia: Bioetanol-növények gyenge talajon" ("Sweet" Energy: Bioethanol plants in weak soil), Haszon Agrár Magazin, pp. 38-39, 2008. (in Hungarian).

[7] Fogarassy, Cs. "Rationalisation of production structure of arable land energy-crops in Hungary", Bodenkultur, 52, pp. 225-231. 2001.

[8] Kovács, G. P. "Cukorcirok termesztési technológia kidolgozása alternatív energetikai célokra" (Development of sweet sorghum cultivation technology for alternative energy purposes), Gödöllő, 2014. [online] Available at: szie.hu. (in Hungarian)

\section{Acknowledgement}

The work reported here was developed in the framework of the project „Implementing a Quality-oriented, Coordinated R\&D\&I Strategy and Working Model at the Budapest University of Technology and Economics" project and supported by the project entitled "Development of integrated agriculture production storage, processing and logistic system for sweet sorghum" (TECH_08_A3/2-2008-0401).

This project was supported by the grant TÁMOP 4.2.1/B-09/1/KMR-2010-0002.

Edit Cséfalvay is grateful for the financial support of János Bolyai Research Scholarship of Hungarian Academy of Sciences.

Special thank to Coopinter Ltd., especially to Nándor Barabás for providing the raw juice samples and the continuous consultation.

The authors greatly acknowledge the support of BASF The Chemical Company, who provided Magnafloc ${ }^{\circledR}$ LT-340 flocculant as polyacrylamide for the clarification experiments in Method 2.

The authors are grateful for Kitti Csendes, Viktória Horváth, Nikoletta Géczi, Renáta Nagy and Lionel Nwgem Kelle for their contribution to the experiments.

[9] Coble, C.G., Egg, R.P., Shmulevich, I. "Processing techniques for ethanol production from sweet sorghum", Biomass, 6, pp. 111117, 1984.

https://doi.org/10.1016/0144-4565(84)90014-3

[10] Cundiff, J. S., Vaughan, D. H. "Sweet sorghum for ethanol industry for the Piedmont", Energy in Agriculture, 6, pp. 133-140, 1987. https://doi.org/10.1016/0167-5826(87)90011-8

[11] Cunningham, R. L., Carlson, K. D., Bagby, M. O. "Extracted sweet sorghum substrates as a source of fermentable sugars", Applied Biochemistry and Biotechnology, 17, pp. 117-124, 1988. https://doi.org/10.1007/BF02779150

[12] Nguyen, M. H. "Suitability of sweet sorghum for alcohol in the Pacific", Energy in Agriculture, 3, pp. 345-350, 1984. https://doi.org/10.1016/0167-5826(84)90045-7

[13] Nguyen, M. H., Prince, R. G. H. "A simple rule for bioenergy conversion plant size optimisation: Bioethanol from sugar cane and sweet sorghum", Biomass and Bioenergy, 10, pp. 361-365, 1996. https://doi.org/10.1016/0961-9534(96)00003-7

[14] Mohite, U., SivaRaman, H. "Continuous conversion of sweet srghum juice to ethanol using immobilized yeast cells", Biotechnology and Bioengineering, 26, pp. 1126-1127, 1984. https://doi.org/10.1002/bit.260260917

[15] Lezinou, V., Christakopoulos, P., Kekos, D., Macris, B.J. "Simultaneous saccharification and fermentation of sweet sorghum carbohydrates to ethanol in a fed-batch process", Biotechnology Letters, 16, pp. 983-988, 1994. https://doi.org/10.1007/BF00128638 
[16] Mamma, D., Koullas, D., Fountoukidis, G., Kekos, D., Macris, B. J., Koukios, E. "Bioethanol from sweet sorghum: Simultaneous saccharification and fermentation of carbohydrates by a mixed microbial culture", Process Biochemistry, 31, pp. 377-381, 1996. https://doi.org/10.1016/0032-9592(95)00075-5

[17] Tengerdy, R. P., Szakacs, G., Sipocz, J. "Bioprocessing of sweet sorghum within situ-produced enzymes", Applied Biochemistry and Biotechnology, 57-58, pp. 563-569. 1996. https://doi.org/10.1007/BF02941736

[18] Bulawayo, B., Bvochora, J. M., Muzondo, M. I., Zvauya, R. "Ethanol production by fermentation of sweet-stem sorghum juice using various yeast strains", World Journal of Microbiology \& Biotechnology, 12, pp. 357-360, 1996. https://doi.org/10.1007/BF00340211

[19] Liu, H., Ren, L., Spiertz, H., Zhu, Y., Xie, G. H. "An economic analysis of sweet sorghum cultivation for ethanol production in North China", GBC Bioenergy, 7, pp. 1176-1184, 2015. https://doi.org/10.1111/gcbb.12222

[20] Goshadrou, A., Karimi, K., Taherzadeh, M. J. "Bioethanol production from sweet sorghum bagasse by Mucor hiemalis", Industrial Crops and Products, 34, pp. 1219-1225, 2011. https://doi.org/10.1016/j.indcrop.2011.04.018

[21] Shen, F., Saddler, J. N., Liu, R., Lin, L., Deng, S., Zhang, Y., Yang, G., Xiao, H., Li, Y. "Evaluation of steam pretreatment on sweet sorghum bagasse for enzymatic hydrolysis and bioethanol production", Carbohydrate Polymers, 86, pp. 1542-1548, 2011. https://doi.org/10.1016/j.carbpol.2011.06.059

[22] Gyalai-Korpos, M., Fülöp, T., Sipos, B., Réczey, K. "Processing sweet sorghum into bioethanol - an integrated approach", Periodica Polytechnica Chemical Engineering, 56, pp. 21-29. 2012. https://doi.org/10.3311/pp.ch.2012-1.03

[23] Heredia-Olea, E., Pérez-Carrillo, E., Serna-Saldívar, S. O. "Production of ethanol from sweet sorghum bagasse pretreated with different chemical and physical processes and saccharified with fiber degrading enzymes", Bioresource Technology, 134, pp. 386-390. 2013 https://doi.org/10.1016/j.biortech.2013.01.162

[24] Wang, L., Luo, Z., Shahbazi, A. "Optimization of simultaneous saccharification and fermentation for the production of ethanol from sweet sorghum (Sorghum bicolor) bagasse using response surface methodology", Industrial Crops and Products, 42, pp. 280-291, 2013. https://doi.org/10.1016/j.indcrop.2012.06.005

[25] Werpy, T., Petersen, G. "Top Value Added Chemicals from Biomass: Volume I -- Results of Screening for Potential Candidates from Sugars and Synthesis Gas", 2004. https://doi.org/10.2172/15008859

[26] Antonopoulou, G., Lyberatos, G. "Effect of Pretreatment of Sweet Sorghum Biomass on Methane Generation", Waste and Biomass Valorization, 4, pp. 583-591. 2012. https://doi.org/10.1007/s12649-012-9183-x

[27] Antonopoulou, G., Gavala, H. N., Skiadas, I. V., Angelopoulos, K., Lyberatos, G. "Biofuels generation from sweet sorghum: Fermentative hydrogen production and anaerobic digestion of the remaining biomass", Bioresource Technology, 99, pp. 110-119. 2008. https://doi.org/10.1016/j.biortech.2006.11.048
[28] Ntaikou, I., Gavala, H.N., Kornaros, M., Lyberatos, G. "Hydrogen production from sugars and sweet sorghum biomass using Ruminococcus albus", International Journal of Hydrogen Energy, 33, pp. 1153-1163. 2008. https://doi.org/10.1016/j.ijhydene.2007.10.053

[29] Shi, X.-X., Song, H.-C., Wang, C.-R., Tang, R.-S., Huang, Z.-X., Gao, T.-R., Xie, J. "Enhanced bio-hydrogen production from sweet sorghum stalk with alkalization pretreatment by mixed anaerobic cultures", International Journal of Energy Research, 34, pp. 662-672. 2010 . https://oi.org/10.1002/er.1570

[30] Boonsayompoo, O., Reungsang, A. "Thermophilic biohydrogen production from the enzymatic hydrolysate of cellulose fraction of sweet sorghum bagasse by Thermoanaerobacterium thermosaccharolyticum KKU19: Optimization of media composition", International Journal of Hydrogen Energy, 38, pp. 15777-15786, 2013.

https://doi.org/10.1016/j.ijhydene.2013.04.129

[31] Calviño, M., Messing, J. "Sweet sorghum as a model system for bioenergy crops", Current Opinion in Biotechnology, 23, pp. 323-329. 2012

https://doi.org/10.1016/j.copbio.2011.12.002

[32] Heredia-Olea, E., Pérez-Carrillo, E., Serna-Saldívar, S. O. "Effects of different acid hydrolyses on the conversion of sweet sorghum bagasse into C5 and C6 sugars and yeast inhibitors using response surface methodology", Bioresource Technology, 119, pp. 216-223, 2012. https://doi.org/10.1016/j.biortech.2012.05.122

[33] Qu, H., Liu, X. B., Dong, C. F., Lu, X. Y., Shen, Y. X. "Field performance and nutritive value of sweet sorghum in eastern China", Field Crops Research, 157, pp. 84-88, 2014. https://doi.org/10.1016/j.fcr.2013.12.010

[34] Richter, K., Trager, A. "L(+)-Lactic acid from sweet sorghum by submerged and solid-state fermentations", Acta Biotechnologica, 14, pp. 367-378. 1994. https://doi.org/10.1002/abio.370140409

[35] Hetényi, K., Gál, K., Németh, Á., Sevella, B. "Use of sweet sorghum juice for lactic acid fermentation: preliminary steps in a process optimization", Journal of Chemical Technology \& Biotechnology, 85, pp. 872-877, 2010. https://doi.org/10.1002/jctb.2381

[36] Yadav, A. K., Bipinraj, N. K., Chaudhari, A. B., Kothari, R. M. "Production of $\mathrm{L}($ ) lactic acid from sweet sorghum, date palm, and golden syrup as alternative carbon sources", Starch - Stärke, 63, pp. 632-636, 2011 https://doi.org/10.1002/star.201100006

[37] Liu, Q., Wang, S., Zhi, J.-F., Ming, H., Teng, D. "Efficient Production of Lactic Acid from Sweet Sorghum Juice by a Newly Isolated Lactobacillus salivarius CGMCC 7.75", Indian Journal of Microbiology, 53, pp. 332-336, 2013. https://doi.org/10.1007/s12088-013-0377-0

[38] Sirisantimethakom, L., Sanchanda, P., Chatleudmongkol, J., Laopaiboon, L., Laopaiboon, P. "Optimization of nutrient supplements for butanol production from sweet sorghum stem juice by Clostridium beijerinckii using an orthogonal array design", Current Opinion in Biotechnology, 24, p. S137, 2013 https://doi.org/10.1016/j.copbio.2013.05.442 
[39] Ntaikou, I., Gavala, H. N., Lyberatos, G. "Application of a modified Anaerobic Digestion Model 1 version for fermentative hydrogen production from sweet sorghum extract by Ruminococcus albus", International Journal of Hydrogen Energy, 35, pp. 3423-3432, 2010. https://doi.org/10.1016/j.ijhydene.2010.01.118

[40] Antonopoulou, G., Gavala, H. N., Skiadas, I. V., Lyberatos, G. "Effect of substrate concentration on fermentative hydrogen production from sweet sorghum extract", International Journal of Hydrogen Energy, 36, pp. 4843-4851, 2011. https://doi.org/10.1016/j.ijhydene.2011.01.077

[41] Di Cai, Chang, Z., Gao, L., Chen, C., Niu, Y., Qin, P., Wang, Z., Tan, T. "Acetone-butanol-ethanol (ABE) fermentation integrated with simplified gas stripping using sweet sorghum bagasse as immobilized carrier" Chemical Engineering Journal, 277, pp. 176-185, 2015. https://doi.org/10.1016/j.cej.2015.04.101

[42] Liang, Y., Sarkany, N., Cui, Y., Yesuf, J., Trushenski, J., Blackburn, J. W. "Use of sweet sorghum juice for lipid production by Schizochytrium limacinum SR21", Bioresource Technology, 101, pp. 3623-3627, 2010.

https://doi.org/10.1016/j.biortech.2009.12.087

[43] Novodárszki, G., Rétfalvi, N., Dibó, G., Mizsey, P., Csefalvay, E., Mika, L. T. "Production of platform molecules from sweet sorghum", RSC Advances, 4, pp. 2081-2088, 2014. https://doi.org/10.1039/c3ra42895h

[44] Tukacs, J.M., Király, D., Strádi, A., Novodárszki, G., Eke, Z., Dibó, G., Kégl, T., Mika, L. T. "Efficient catalytic hydrogenation of levulinic acid: a key step in biomass conversion", Green Chemistry, 14, pp. 2057-2065, 2012. https://doi.org/10.1039/C2GC35503E

[45] Tukacs, J. M., Jones, R. V., Darvas, F., Dibó, G., Lezsák, G., Mika, L. T. "Synthesis of $\gamma$-valerolactone using a continuous-flow reactor", RSC Advances, 3, pp. 16283-16287, 2013. https://oi.org/10.1039/C3RA43032D

[46] Tukacs, J. M., Novák, M., Dibó, G., Mika, L. T. "An improved catalytic system for the reduction of levulinic acid to $\gamma$-valerolactone", Catalysis Science \& Technology, 4, pp. 2908-2912, 2014. https://doi.org/10.1039/C4CY00719K

[47] Fábos, V., Mika, L. T., Horváth, I. T. "Selective Conversion of Levulinic and Formic Acids to $\gamma$-Valerolactone with the Shvo Catalyst", Organometallics, 33, pp. 181-187, 2014. https://doi.org/10.1021/om400938h

[48] Tukacs, J. M., Fridrich, B., Dibó, G., Székely, E., Mika, L. T. "Direct asymmetric reduction of levulinic acid to gamma-valerolactone: synthesis of a chiral platform molecule", Green Chemistry, 17, pp. 5189-5195, 2015. https://doi.org/10.1039/C5GC01099C

[49] Tanamool, V., Imai, T., Danvirutai, P., Kaewkannetra, P. "Biopolymer generation from sweet sorghum juice: screening, isolation, identification, and fermentative polyhydroxyalkanoate production by Bacillus aryabhattai", Turkish Journal of Biology, 37, pp. 259-264, 2013. https://doi.org/10.3906/biy-1205-62

[50] Németh, Á., Sevella, B. "Technological improvements on sweet sorghum based biorefinery", New Biotechnology, 29, pp. S6-S7, 2012. https://doi.org/10.1016/j.nbt.2012.08.010
[51] Yu, J., Zhang, T., Zhong, J., Zhang, X., Tan, T. "Biorefinery of sweet sorghum stem", Biotechnology Advances, 30, pp. 811-816, 2012. https://doi.org/10.1016/j.biotechadv.2012.01.014

[52] Csefalvay, E., Horváth, I. T. "Chemicals from renewable feedstocks", McGraw-Hill Yearbook of Science and Technology, AccessScience, New York, 2013. https://doi.org/10.1036/1097-8542.yb130337

[53] Whitfield, M. B., Chinn, M. S., Veal, M. W. "Processing of materials derived from sweet sorghum for biobased products", Industrial Crops and Products, 37, pp. 362-375, 2012. https://doi.org/10.1016/j.indcrop.2011.12.011

[54] Ratnavathi, C. V., Chakravarthy, S. K., Komala, V. V., Chavan, U. D., Patil, J. V. "Sweet Sorghum as Feedstock for Biofuel Production: A Review", Sugar Tech, 13, pp. 399-407, 2011. https://doi.org/10.1007/s12355-011-0112-2

[55] Regassa, T. H., Wortmann, C. S. "Sweet sorghum as a bioenergy crop: Literature review", Biomass and Bioenergy, 64, pp. 348-355, 2014. https://doi.org/10.1016/j.biombioe.2014.03.052

[56] Eiland, B. R., Clayton, J. E., Bryan, W. L. "Losses of Fermentable Sugars in Sweet Sorghum During Storage", Transactions of the ASAE, 26(5), pp. 1596-1600, 1983. https://doi.org/10.13031/2013.34176

[57] Jasberg, B. K., Montgomery, R. R., Anderson, R. A. "Preservation of Sweet Sorghum Biomass", Biotechnology and Bioengineering Symposium, (13), pp. 113-120, 1983.

[58] Eckhoff, S. R., Bender, D. A., Okos, M. R., Peart, R. M. "Preservation of Chopped Sweet Sorghum Using Sulfur Dioxide", Transactions of the ASAE, 28(2), pp. 0606-0609, 1985. https://doi.org/10.13031/2013.32306

[59] Yu, J., Zhong, J., Zhang, X., Tan, T. "Ethanol Production from H2SO3-Steam-Pretreated Fresh Sweet Sorghum Stem by Simultaneous Saccharification and Fermentation", Applied Biochemistry and Biotechnology, 160, pp. 401-409, 2008. https://doi.org/10.1007/s12010-008-8333-x

[60] Shen, F., Liu, R. "Storage of Sweet Sorghum Fresh Juice with Ethyl-p-Hydroxybenzoate and the Ethanol Fermentation with the Preserved Juice", Journal of Biobased Materials and Bioenergy, 4, pp. 324-329, 2010. https://doi.org/10.1166/jbmb.2010.1095

[61] Wu, X., Staggenborg, S., Wang, D. "Stabilization of Sweet Sorghum Juice for Long-Term Storage", Transactions of the ASABE, 58(1), pp. 169-175, 2015. https://doi.org/10.13031/trans.58.10841

[62] Lingle, S. E. "Opportunities and Challenges of Sweet Sorghum as a Feedstock for Biofuel", In: Sustainability of the Sugar and Sugar-Ethanol Industries, ACS Symposium Series, American Chemical Society, Washington, DC, 2010, pp. 177-188. https://doi.org/10.1021/bk-2010-1058.ch011

[63] Chen, J. C. P. "Can sugar be made out of sweet sorghum?", Sugar Journal, 44, p. 12, 1981.

[64] Angelle, P. "Sweet sorghum pilot program", Sugar Journal, 44, pp. 17-18, 1982.

[65] Eggleston, G., Vercellotti, J. R. "Degradation of Sucrose, Glucose and Fructose in Concentrated Aqueous Solutions Under Constant pH Conditions at Elevated Temperature", Journal of Carbohydrate Chemistry, 19, pp. 1305-1318, 2000. https://oi.org/10.1080/07328300008544153 
[66] De Bruijn, J. M. "Monosaccharides in alkaline medium: Isomerization, degradation, oligomerization", $\mathrm{PhD}$ Theses, Delft University of Technology, 1986.

[67] Eggleston, G., Cole, M., Andrzejewski, B. "New Commercially Viable Processing Technologies for the Production of Sugar Feedstocks from Sweet Sorghum (Sorghum bicolor L. Moench) for Manufacture of Biofuels and Bioproducts", Sugar Tech, 15, pp. 232-249, 2013. https://doi.org/10.1007/s12355-013-0229-6

[68] Kim, M., Han, K.-J., Jeong, Y., Day, D. F. "Utilization of whole sweet sorghum containing juice, leaves, and bagasse for bio-ethanol production", Food Science and Biotechnology, 21, pp. 10751080. 2012.

https://doi.org/10.1007/s10068-012-0139-5

[69] Eggleston, G., Heckemeyer, M., Cyr, E. S., Wartelle L. "Case Study: Commercialization of Sweet Sorghum Juice Clarification for LargeScale Syrup Manufacture", Sugar Tech, 18, pp. 249-257, 2016. https://doi.org/10.1007/s12355-015-0387-9

[70] Eggleston, G., Amorim, H. "Reasons for the chemical destruction of sugars during the processing of sugarcane for raw sugar and fuel alcohol production", International Sugar Journal, 108, pp. 271-282, 2006.

[71] Andrzejewski, B., Eggleston, G., Lingle, S., Powell, R. "Development of a sweet sorghum juice clarification method in the manufacture of industrial feedstocks for value-added fermentation products", Industrial Crops and Products, 44, pp. 77-87, 2013. https://doi.org/10.1016/j.indcrop.2012.10.028

[72] Andrzejewski, B., Eggleston, G., Powell, R. "Pilot plant clarification of sweet sorghum juice and evaporation of raw and clarified juices", Industrial Crops and Products, 49, pp. 648-658, 2013. https://doi.org/10.1016/j.indcrop.2013.06.027

[73] Eggleston, G., Montes, B., Heckemeyer, M., Triplett, A., Stewart, D., Lima, I., Cole, M. "Problems, control, and opportunity of starch in the large scale processing of sugarcane and sweet sorghum", International Sugar Journal, 120, pp. 698-707, 2017.

[74] Eggleston, G., DeLucca, A., Sklanka, S., Dalley, C., Cyr, E.S., Powell, R. "Investigation of the stabilization and preservation of sweet sorghum juices", Industrial Crops and Products, 64, pp. 258-270, 2015.

https://doi.org/10.1016/j.indcrop.2014.09.008

[75] Broadhead, D. M. "Effects of Stalk Chopping on Leaf Removal and Juice Quality of Rio Sweet Sorghum1", Agronomy Journal, 64(3), pp. 306-308, 1972.

https://doi.org/10.2134/agronj1972.00021962006400030014x
[76] Service, H.M. 2015. Annual precipitations.

[77] Zegada-Lizarazu, W., Monti, A. "An Integrated Approach to Harvest and Storage of Sweet Sorghum at Farm Scale", BioEnergy Research, 8, pp. 450-458, 2014. https://doi.org/10.1007/s12155-014-9533-6

[78] Environment, M. O., Water, "Útmutató az elérhető legjobb technika meghatározásához a cukorgyártás terén" (Guideline on the best available techniques in sugar manufacturing industry), 2005. (in Hungarian) [online] Available at: https://ippc.kormany.hu

[79] India, T. I., Intertraverz Co, H. "Analysis of sweet sorghum juice and syrup", 2015.

[80] Namiki, M., Hayashi, T. "A New Mechanism of the Maillard Reaction Involving Sugar Fragmentation and Free Radical Formation", ACS Symposium Series, 215, 1983. https://doi.org/10.1021/bk-1983-0215.ch002

[81] Bakacsi, Z. "A cukorcirok préslé membránszeparációs betöményítésének léptéknövelése" (Scale-up of sweet sorghum juice concentration process by membrane separation), 2015. (in Hungarian).

[82] Puskás, A., Erdélyi, A., Gruiz, K., Janzsó, B., Pap, G., Törley, D. "Ipari mikrobiológiai gyakorlatok" (Industrial microbiological practices), Budapest. (n.d.) (in Hungarian)

[83] Cséfalvay, E., Csendes, K. A., Horváth, V., Stelén, G. "Cukorcirok szirup előállítási technológia fejlesztése laboratóroumi körülmények között" (Development of sweet sorgum syrup production technology at laboratory scale), Energiagazdálkodás, 56/5-6, pp. 36-40, 2015. (in Hungarian)

[84] Sasaki, K., Tsuge, Y., Sasaki, D., Teramura, H., Wakai, S., Kawaguchi, H., Sazuka, T., Ogino, C., Kondo, A. "Increased ethanol production from sweet sorghum juice concentrated by a membrane separation process", Bioresource Technology, 169, pp. 821-825, 2014. https://doi.org/10.1016/j.biortech.2014.07.082

[85] Nagy, R., Csefalvay, E., Mizsey, P. "Cukorcirok préslé cukortartalmának betöményítése bionyersanyag elökészítéshez"(Concentration of sweet sorghum juice's sugar content for preparation of bio raw materials), Membrántechnika és ipari biotechnológia, 3, pp. 39-51, 2011. (in Hungarian).

[86] Eggleston, G., Andrzejewski, B., Cole, M., Dalley, C., Sklanka, S., St Cyr, E., Chung, Y.-J., Powell, R. "Novel storage technologies for raw and clarified syrup biomass feedstocks from sweet sorghum (Sorghum bicolor L. Moench)", Biomass and Bioenergy, 81, pp. 424-436, 2015.

https://doi.org/10.1016/j.biombioe.2015.07.013 